\title{
Measuring methane emissions from a UK landfill using the tracer dispersion method and the influence of operational and environmental factors
}

Rees-White T.C. ${ }^{1}$, Mønster, J. ${ }^{2}$, Beaven R.P. ${ }^{1}$, Scheutz, C. ${ }^{2 *}$

${ }^{1}$ Faculty of Engineering and the Environment, University of Southampton, Southampton, SO17 1BJ, UK.

${ }^{2}$ Department of Environmental Engineering, Technical University of Denmark, $2800 \mathrm{Kgs}$. Lyngby, Denmark.

*Corresponding author

Keywords: landfill gas, municipal solid waste, gas collection efficiency, barometric pressure, wind speed

\section{Highlights:}

- Over 120 downwind landfill methane emission transects undertaken

- Monitoring successful between 2000 and $6700 \mathrm{~m}$ downwind

- Negative correlation between wind speed and emissions

- Difficult to isolate environmental influences from potential experimental error

- Tracer technique used to estimate methane emissions from gas engine

- $69 \%$ methane capture and recovery

\footnotetext{
* NOTICE: this is the authors' version of a work that was accepted for publication in Waste Management. Changes resulting from the publishing process, such as peer review, editing, corrections, structural formatting, and other quality control mechanisms may not be reflected in this document. Changes may have been made to this work since it was submitted for publication. A definitive version was subsequently published in Waste Management https://doi.org/10.1016/j.wasman.2018.03.023
} 


\begin{abstract}
The methane emissions from a landfill in south-east, UK were successfully quantified during a six-day measurement campaign using the tracer dispersion method. The fair weather conditions made it necessary to perform measurements in the late afternoon and in the evening when the lower solar flux resulted in a more stable troposphere with a lower inversion layer. This caused a slower mixing of the gasses, but allowed plume measurements up to $6700 \mathrm{~m}$ downwind from the landfill. The average methane emission varied between $217 \pm 14$ and $410 \pm 18 \mathrm{~kg} \mathrm{~h}^{-1}$ within the individual measurement days, but the measured emission rates were higher on the first three days $\left(333 \pm 27,371 \pm 42\right.$ and $\left.410 \pm 18 \mathrm{~kg} \mathrm{~h}^{-1}\right)$ compared to the last three days $\left(217 \pm 14,249 \pm 20\right.$ and $\left.263 \pm 22 \mathrm{~kg} \mathrm{~h}^{-1}\right)$. It was not possible to completely isolate the extent to which these variations were a consequence of measuring artefacts, such as wind/measurement direction and measurement distance, or from an actual change in the fugitive emission. Such emission change is known to occur with changes in the atmospheric pressure. The higher emissions measured during the first three days of the campaign were measured during a period with an overall decrease in atmospheric pressure (from approximately 1014 mbar on day 1 to 987 mbar on day 6). The lower emissions measured during the last three days of the campaign were carried out during a period with an initial pressure increase followed by a period of slowly reducing pressure. The average daily methane recovery flow varied between 633 and $679 \mathrm{~kg} \mathrm{~h}^{-1}$ at STP $\left(1 \mathrm{~atm}, 0^{\circ} \mathrm{C}\right)$. The methane emitted to the atmosphere accounted for approximately $31 \%$ of the total methane generated, assuming that the methane generated is the sum of the methane recovered and the methane emitted to the atmosphere, thus not including a potential methane oxidation in the landfill cover soil.
\end{abstract}




\section{Introduction}

Methane is a potent greenhouse gas (GHG) and the anthropogenic emission of methane to the atmosphere contributes to climate change. Worldwide emissions from the waste sector have been estimated to account for $18 \%$ of the global anthropogenic methane emitted in 2004 (Bogner et al., 2008), with landfills accounting for a large proportion of this (IPCC, 2007). There are a variety of mitigation measures, which can reduce emissions of methane from landfills, including the installation of low permeability caps and the operation of engineered gas recovery and control systems, which primarily reduce the potential for advective methane release. Landfill covers may also be designed to optimise biological methane oxidation using biocover systems (Scheutz et al., 2014; Scheutz et al., 2011a), and considerable recent research has been directed towards understanding this GHG emission abatement process (Scheutz et al., 2009; Molins et al., 2008; Scheutz et al., 2004).

The spatial variability of landfill methane emissions is well recognised (Rachor et al., 2013; Bogner et al., 2011; Gebert et al., 2011), especially when related to the presence/absence and properties of top covers. The age and biological activity of the underlying waste is also of importance.

Many processes affect temporal variations in landfill gas (LFG) emissions, such as atmospheric pressure variations from the passage of weather systems, and shorter duration wind turbulence-induced pressure fluctuations (e.g. Dalkesh et al., 2016; Poulsen et al., 2006). Most studies have shown that it is the change in barometric pressure, rather than the absolute pressure, that affects the emission from a landfill (Xu et al., 2014; Fredenslund et al., 2010; Gebert and Groengroeft, 2006; Poulsen et al., 2003; Nastev et al., 2001; Young, 1992 \& 1990). Soil and air temperature may also impact LFG emissions (Uyanik et al., 2012; Christophersen et al., 2001). Temporal variations in emissions have also been related to seasonal variations in methane oxidation (Spokas et al., 2011; Christophersen and Kjeldsen 2001; Christophersen et al., 2001). Bogner et al. (2011) quantified the seasonal variability of methane, carbon dioxide, and nitrous oxide emissions from fresh refuse with no cover and with daily, intermediate, and final cover materials at various California landfill sites. Most studies on temporal variations in LFG emissions have been based on modelling or from measurements made using surface flux chambers measuring emissions from localised areas of the landfill cover. Currently, the knowledge on whole landfill emission dynamics is very limited.

Various measuring methods have been used to determine fugitive methane emission rates from landfills. The method specified in the UK's Environment Agency (EA) guidance (Environment Agency, 2004 \& 2010) is based on surface flux chamber techniques, and many studies (Abichou et al., 2011; Scheutz et al., 2003 \& 2008; Park \& Shin, 2001; Börjesson et al., 2000) have been carried out using this method. Although recognised as a cost effective technique that is easy to use, static chamber methods have been widely criticised as not being able to quantify accurately the often point source nature of LFG emissions. A second approach to LFG emission quantification, involves optical methods to characterise abovebackground concentrations of methane in 2D transects over or downwind of a landfill (e.g. Robinson et al., 2011). The methane flux is determined by integrating the results with a wind vector map. Thirdly, tracer gas dispersion techniques have been under continual development, especially in response to improvements in the portability and range of trace gases that can be analysed by field-employable instruments. Current state of the art tracer gas dispersion measurements for determining methane emissions from landfills involve using acetylene as the tracer gas, released on or close to the landfill. Measurements of the tracer gas and methane concentrations are made downwind of the source. Mønster et al. (2014 \& 2015) describe the use of the technique in 15 landfills in Denmark. The tracer gas dispersion 
technique relies on the assumption that full mixing between the tracer and landfill plume has occurred at the point of monitoring.

The main objective of this study was to quantify the total methane emission from a landfill in the UK by application of the tracer gas dispersion method (TDM), and to investigate temporal emission variations over the course of the monitoring. Finally, an attempt to identify emissions arising specifically from non-combusted methane emitted from on-site landfill gas engines was conducted and the gas collection efficiency was determined. The measurement campaign was carried out between August $5^{\text {th }}$ and $12^{\text {th }} 2014$, and included more than 120 methane plume transects. Two months prior to the field campaign, a scoping trial consisting of two TDM experiments (on $11^{\text {th }}$ and $12^{\text {th }}$ June 2014) was carried out. The data generated in this earlier trial is included in the paper for comparison and completeness. This study measured whole-site landfill methane emission rates over six days and contributes to the very limited knowledge on landfill scale emission dynamics.

\section{Methodology}

\subsection{Description of Landfill}

The TDM experiments were carried out at a landfill in the south-east of the UK. The site has been in operation since 1992 and is licensed to receive a mixture of waste including domestic, commercial and industrial wastes, oil contaminated wastes, contaminated soils and asbestos. On average, the landfill has received between 200,000 to 500,000 tonnes of waste annually, mainly domestic, construction and industrial wastes, and soils. Since opening, the site has taken $6.3 \mathrm{Mt}$ waste to the end of 2013.

The site is comprised of 11 cells, covering an area of approximately $330,000 \mathrm{~m}^{2}$. The cells were constructed with an engineered base of 225 to $300 \mathrm{~mm}$ bentonite enriched soil and a $2 \mathrm{~mm}$ high-density polyethylene (HDPE) synthetic liner. The majority of the landfill is filled to final levels and has been restored, with just a small operational area remaining in the centre of the site. The northern parts of the site are capped and fully restored with a $1 \mathrm{~mm}$ LDPE liner overlain by restoration soils, and to the east, the waste has been capped with a 1 $\mathrm{mm}$ LDPE liner, but at the time of the study had no restoration material. The fully restored area has a maximum elevation of $62 \mathrm{mASL}$ (Above Sea Level), forming a steep ridge above the operational area. The ground is relatively flat, gently sloping to the north and east to an elevation of $\sim 45 \mathrm{mASL}$. The partially restored area is in the form of an asymmetrical dome, with a maximum height of $58 \mathrm{mASL}$, rising from $\sim 40 \mathrm{mASL}$ at the edges. The operational area is relatively level, with an elevation of $\sim 44 \mathrm{mASL}$. Fig. 1 shows an outline of the landfill, with the approximate areas of restoration, the operational area and the gas utilisation plant (GUP).

An active gas management system is in operation at the landfill, comprising of a network of gas extraction wells, connected to a system of gas mains and spurs. The gas collection system directs collected gas to the GUP, which has four LFG engines and a flare. During the course of the TDM experiments, either two or three of the four engines were in operation. When only two engines were operating, a flare was used to burn excess LFG. Flow through the plant during the trials, averaged $1900 \mathrm{~m}^{3} \mathrm{~h}^{-1}$, with an average mass of $660 \mathrm{~kg}$ methane $\mathrm{h}^{-1}$. The plant has a capacity of around $3 \mathrm{MW}$. 


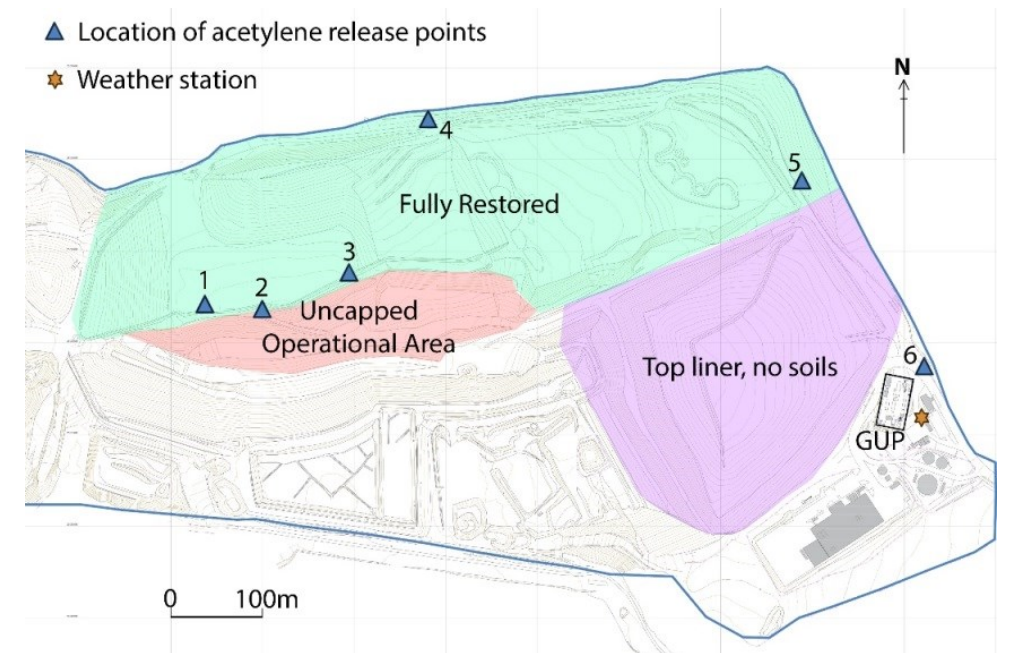

Fig. 1. Plan of landfill showing fully and partly restored areas, the active (operational) filling area, gas utilisation plant (GUP), weather station and location of tracer gas cylinders (1 to 6).

\subsection{Dynamic plume measurement using a mobile analytical platform}

Total landfill methane emissions were quantified using a mobile tracer dispersion method that combines a controlled release of tracer gas from the landfill with methane and tracer gas concentration measurements downwind of the landfill using a mobile highresolution analytical instrument (Scheutz et al., 2011b; Börjesson et al., 2009 \& 2007; Galle et al., 2001). The method has been used successfully since the 1990s, and with new developments in analytical technology it has become a powerful tool for quantifying methane emissions from landfills (Mønster et al., $2014 \&$ 2015). The TDM is based on the assumption that a tracer gas released at an emission source, in this case a landfill, will disperse in the atmosphere in the same way as methane emitted from the landfill will disperse. Assuming a defined wind direction, well mixed air above the landfill (causing the emitted methane and released tracer gas to be fully mixed), and a constant tracer gas release, the methane emission rate can be calculated as a function of the ratio of the integrated cross-plume concentration of the emitted methane and the integrated cross-plume concentration of the released tracer gas, as follows:

$$
E_{\text {gas }}=Q_{\text {tracer }} \cdot \frac{\int_{\text {Plume end } 1}^{\text {Plume end } 2} C_{\text {Pase end } 2} d x}{\int_{\text {Plume end } 1}^{1} C_{\text {tracer }} d x} \cdot \frac{M W_{\text {gas }}}{M W_{\text {tracer }}}
$$

Where $E_{\text {gas }}$ is the methane emission rate $\left(\mathrm{kg} \mathrm{h}^{-1}\right), Q_{\text {tracer }}$ is the release rate of the tracer gas $(\mathrm{kg}$ $\left.\mathrm{h}^{-1}\right), C_{\text {gas }}$ and $C_{\text {tracer }}$ denote cross-plume concentrations above the background concentration, $M W$ denotes molecular weights and $x$ corresponds to distance across the plume.

Measurements were performed with a cavity ring-down spectroscopy methane/acetylene analyser (G2203, Picarro Inc., USA). Atmospheric air was sampled from the roof of the monitoring vehicle and brought to the analyser via an external pump, enabling a fast response time while driving. The atmospheric concentrations of methane, acetylene and water were measured with a frequency of $2 \mathrm{~Hz}$ and logged together with the vehicle's position. The precision of the methane and acetylene measurements was $0.48 \mathrm{ppb}$ and 0.40 ppb respectively, making it possible to detect small changes in atmospheric concentrations 
whilst driving. The accuracy of the instrument is regularly checked using certified gasses. If the instrument has drifted, then a zero-span calibration is performed in the linear concentration region of the specific gas. The linear concentration region is certified by the manufacturer. Position was logged using a GNSS (Global Navigation Satellite System) receiver (model R330 GNSS Receiver and A101 Smart Antenna, Hemisphere, Canada), measured to within $0.20 \mathrm{~m}$.

Tracer gas cylinders (15.9 litre) (BOC Industrial Gases, cylinder size J) filled with $\sim 2.35 \mathrm{~kg}$ dissolved acetylene $(98.5 \%$ purity) were used to release the tracer gas at the landfill. The rate of release was controlled manually using valves and calibrated flow meters (Shorate, Brooks Instrument), with periodic checks during a release to maintain stable flow rates. The accuracy of the flow meters was previously demonstrated in the laboratory to be better than $3 \%$. The calculated mass of tracer release was corrected for the $98.5 \%$ purity of the acetylene in the gas cylinders and ranged from 2.6 to $3.5 \mathrm{~kg} \mathrm{~h}^{-1}$, with either three or four tracer gas cylinders in use at a time. Flow was identical from each cylinder during a given test.

The tracer gas cylinders were placed in areas of the landfill with the highest methane emissions in order to simulate emissions in the best possible way. Due to access restrictions at the time of the trials, it was not possible to carry out on-site screening prior to the tests described. However, a scoping trial including on-site methane screening had been carried out in June 2014, and it was assumed that relative methane emissions across the site would have been the same. The highest concentrations were measured near the ridge between the operational area and the older, fully restored area with gas extraction wells. For safety reasons, it was not possible to place cylinders on the steep ridge or in the operational area, therefor cylinders were located at the top of the ridge. Elevated methane concentrations were also measured downwind from the GUP. The location of the tracer gas cylinders is shown in Fig. 1 and details of the cylinders used in individual tests given in Table 1.

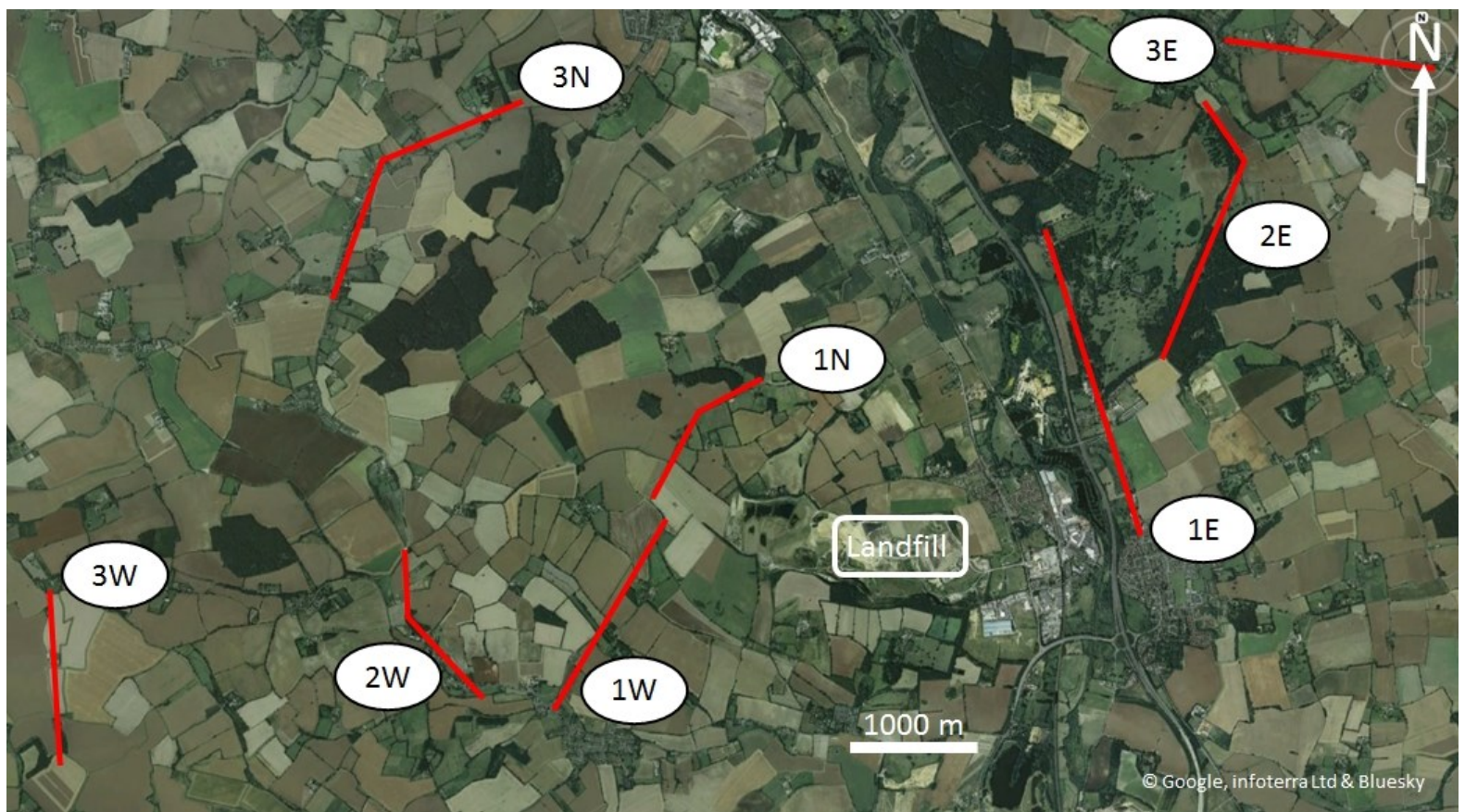

Fig. 2. A Google Earth image showing land use (terrain) around the landfill and monitoring routes used during the August campaign to collect air concentration data (Google Earth, 2017). 
Table 1. Overview of the measurement campaign showing measuring dates, measuring distance, measurement road, and number of plume transects made, wind speed and direction, approximate gas travel time, tracer release points and tracer release rate.

\begin{tabular}{|c|c|c|c|c|c|c|}
\hline $\begin{array}{l}\text { Test no. / } \\
\text { Date }\end{array}$ & $\begin{array}{l}\text { Measuring } \\
\text { time interval }\end{array}$ & $\begin{array}{l}\text { Road }^{\mathrm{b}} \text {, measuring } \\
\text { distance to the landfill } \\
(\mathrm{m}) \text { and total number } \\
\text { of plume transects } \\
\text { made }(n)\end{array}$ & $\begin{array}{l}\text { Avg. wind } \\
\text { speed } \\
\left(\mathrm{m} \mathrm{s}^{-1}\right),(\mathrm{SD}) \\
\text { and } \\
\text { dominant } \\
\text { direction }\end{array}$ & $\begin{array}{l}\text { Approx. } \\
\text { travel time } \\
\text { from point } \\
\text { of release } \\
\text { to first } \\
\text { monitorin } \\
\text { g point } \\
\text { (mins) }\end{array}$ & $\begin{array}{l}\text { Tracer gas } \\
\text { release } \\
\text { points } \\
\text { (refer to } \\
\text { Fig. 1) }\end{array}$ & $\begin{array}{l}\text { Total tracer } \\
\text { gas release } \\
\text { rate } \\
\left(\mathrm{kg} \mathrm{h}^{-1}\right)\end{array}$ \\
\hline $\begin{array}{c}\text { TDM } 1 \\
06.08 .2014\end{array}$ & $17: 20-19: 00$ & (1E) $1700-2000(18)$ & $\begin{array}{c}7.5(1.4) \\
W\end{array}$ & 5 & $1,3,4,5$ & 3.35 \\
\hline $\begin{array}{c}\text { TDM } 2 \\
07.08 .2014\end{array}$ & $18: 00-22: 20$ & $\begin{array}{c}(1 \mathrm{~W}) 2000(10) \\
(2 \mathrm{~W}) 3500-4000(13) \\
(3 \mathrm{~W}) 6700(8)\end{array}$ & $\begin{array}{c}3.4(2.3) \\
E\end{array}$ & 10 & $1,2,3,5$ & 3.48 \\
\hline $\begin{array}{c}\text { TDM } 3 \\
08.08 .2014\end{array}$ & $16: 30-19: 15$ & $\begin{array}{c}(1 \mathrm{~W} / 1 \mathrm{~N}) 1600-2000 \\
(9) \\
(2 \mathrm{~N}) 3000(5) \\
(3 \mathrm{~N}) 4500-5000(6)\end{array}$ & $\begin{array}{c}4.3(2.2) \\
\mathrm{SE}\end{array}$ & 8 & $1,3,5$ & 2.55 \\
\hline $\begin{array}{c}\text { TDM } 4 \\
11.08 .2014\end{array}$ & $16: 30-18: 15$ & (1E) $1700-2000(15)$ & $\begin{array}{c}9.3(1.3) \\
\text { SW }\end{array}$ & 4 & $1,3,4,5$ & 2.6 \\
\hline $\begin{array}{c}\text { TDM 5 } \\
12.08 .2014\end{array}$ & $16: 30-18: 30$ & $\begin{array}{l}\text { (1E) } 1700-3000(15) \\
\text { (2E) } 2500-4200(1) \\
\text { (3E) } 4800-6000(5)\end{array}$ & $\begin{array}{l}9.7(0.9) \\
\text { WSW }\end{array}$ & 5 & $1,4,5,6$ & 2.58 \\
\hline $\begin{array}{c}\text { TDM } 6 \\
13.08 .2014\end{array}$ & $08: 15-09: 15$ & (1E) $1700-2000(17)$ & $\begin{array}{c}7.8(0.7) \\
W\end{array}$ & 4 & $1,3,5,6$ & 2.59 \\
\hline $\begin{array}{c}\text { TDM J1 }{ }^{\mathrm{a}} \\
11.06 .2014\end{array}$ & $18: 46-18: 55$ & (1S) $1400-1700(5)$ & $\begin{array}{c}4.2(1.6) \\
\mathrm{NW}\end{array}$ & 7 & $1,2,3$ & 1.10 \\
\hline $\begin{array}{c}\mathrm{TDM} \mathrm{J}^{\mathrm{a}} \\
12.06 .2014\end{array}$ & $8: 05-8: 47$ & (1S) $1400-1700(11)$ & $\begin{array}{c}3.4(1.7) \\
\text { NW }\end{array}$ & 8 & $1,2,3,4$ & 2.60 \\
\hline
\end{tabular}

${ }^{a}$ Data from the scoping performed in June 2014 is also given for comparison.

\subsection{Description of the measurement campaign}

Before the TDM emission quantifications were carried out, screening of methane and acetylene concentrations were carried out around the landfill to establish the location and extent of the methane plume, the background concentration of each gas, and to identify any other sources of the gases which could potentially interfere with the quantification of the methane plume from the landfill.

Downwind TDM measurements were carried out by driving the monitoring vehicle along public highways around the landfill in all directions, with distance and location varying depending on the wind direction, the degree of dispersion, the accessibility of roads, and possible interference with other methane sources. Measurements were carried out at different times of day and with the wind from different directions.

The optimal distance for measuring a site's total emissions depends on the size of the emission area, the topography of the site, weather conditions such as wind speed and solar radiation (Mønster et al., 2014), and the sensitivity of the analytical platform. The plume measurements were made at a distance of between 1600 and $6700 \mathrm{~m}$ from the landfill. Methane quantification was carried out by performing multiple transects across the plume and then calculating the methane/tracer ratio (Eq. 1) for each transect. In this way, a change in dilution due to a change in wind speed, or turbulence changing vertical mixing, would be the same for both gasses at each individual plume measurement. For each plume transect, it 
was ensured that the whole plume was measured before turning the vehicle to measure the plume again. This enabled the establishment of a baseline of background concentrations to be subtracted from the measurements in order to obtain the landfill's contribution to the plume. Each plume transect measurement took between 1 and $10 \mathrm{~min}$ to perform. The transect time depended on the width of the plume and driving speed, which was typically between 20-30 $\mathrm{km} \mathrm{h}^{-1}$, depending on road and traffic conditions.

In total, six TDM experiments were performed, each consisting of one to three hours of acetylene release and downwind monitoring. For a given test, measurements were performed at up to three different distances to the landfill and in different directions from the landfill, depending on the wind direction and intensity at the time of the measurement (Fig. 2 ). To ensure that the tracer gas had had sufficient time to travel from the release location to the point of monitoring at the start of a test, roads closest to the landfill were monitored first, before moving progressively further away. Table 1 provides an overview of each test, including information on measuring dates, weather conditions (average wind speed and direction and atmospheric pressure), tracer gas release (number of tracer gas release points and total release rates), and measurement transects (measuring distance and number of transects performed).

Measurements were made during a period of relatively warm and sunny weather. These conditions can result in a faster plume rise, and make afternoon and evening measurements preferable for measuring methane and tracer gas at greater distances from the landfill. Fig. 3 and 4 show the atmospheric pressure, local wind speed, incoming solar radiation and temperature in the period of August $3^{\text {th }}$ to August $14^{\text {th }} 2014$, measured at the site's static weather station (SkyView, model unknown) located at the weighbridge. The weather station provided 30 minute averages of continually monitored meteorological data. The figures show data during the measurement period and either side of the campaign. The weather conditions (atmospheric pressure and wind speed) during the measurements are summarized in Table 1. Solar radiation during the TDMs was generally positive, resulting in unstable atmospheric conditions. The one exception was the last part of TDM2 after 9pm when solar radiation reduced to zero. The weather data reported in Table 1 is the average of the landfill weather station's readings over the course of each TDM test.

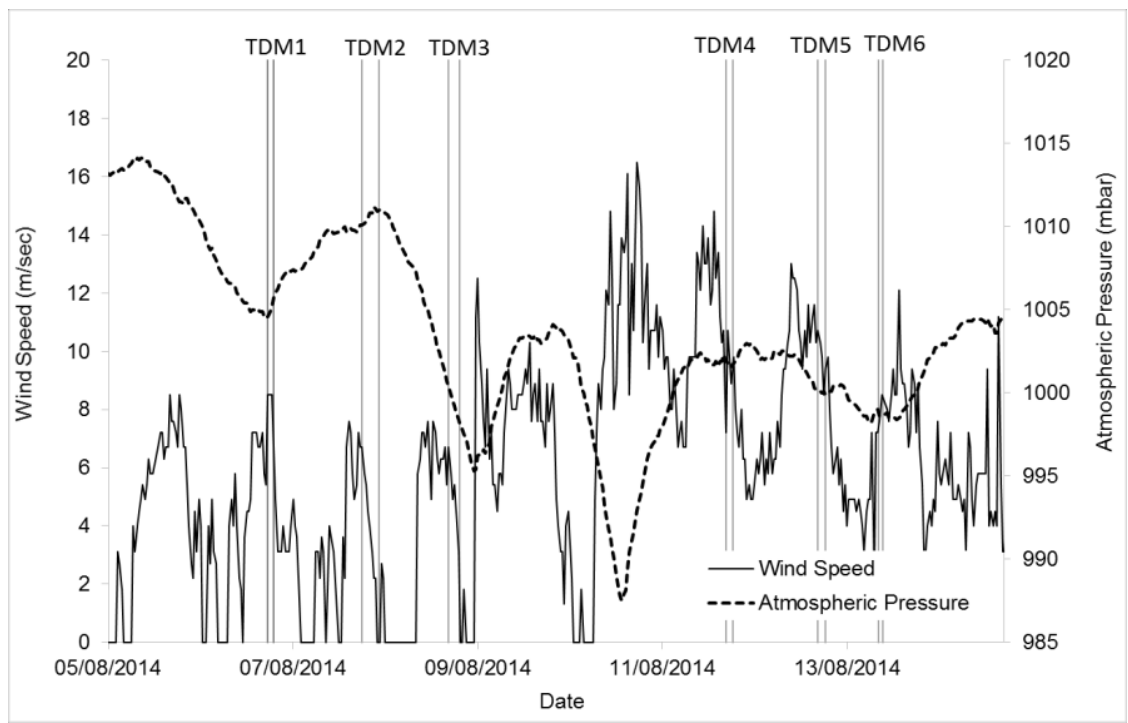

Fig. 3. Atmospheric pressure and wind speed during the period of August $5^{\text {th }}$ to August $14^{\text {th }}$, 2014. Start and end times of each TDM experiment are given as vertical lines. 


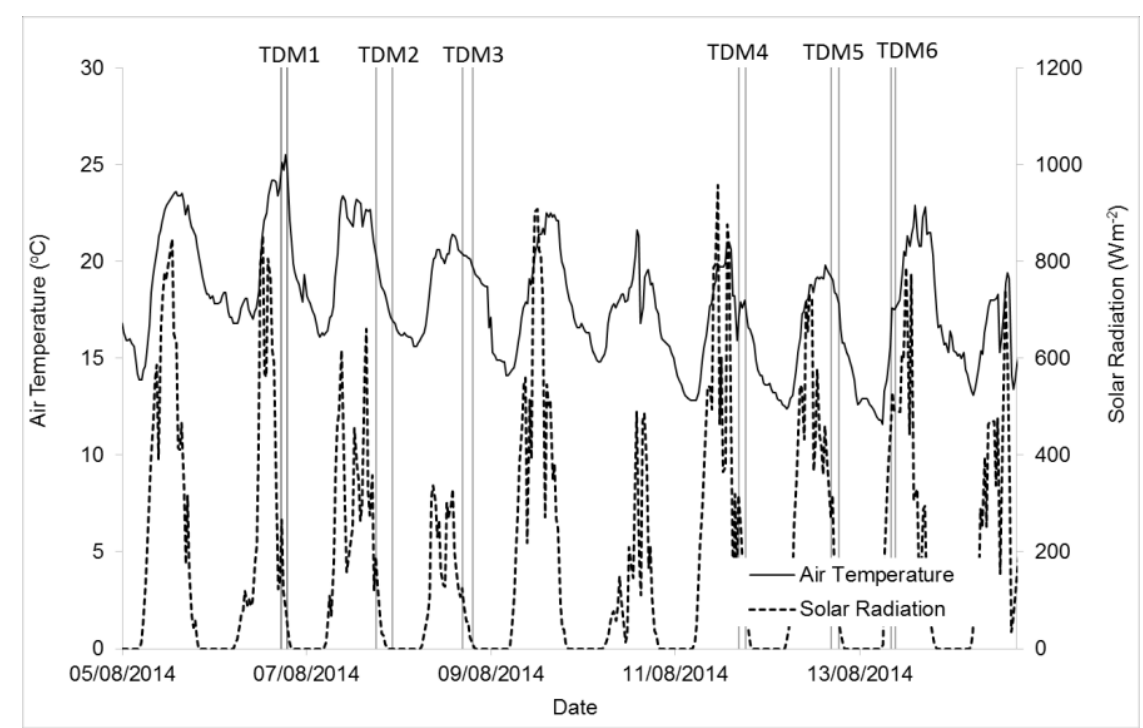

Fig. 4. Incoming solar radiation and air temperature during the period of August $3^{\text {th }}$ to August $14^{\text {th }}, 2014$. Start and end times of each TDM experiment are given as vertical lines.

\subsection{Data processing}

Between 15 and 31 plume transects were made in each TDM (Table 1). A visual screening of each transect was made to check for anomalous data and excess noise, which may be caused by instrument error, changing weather patterns and from interfering methane or acetylene sources. Plume traverses were excluded if they were performed outside of the tracer gas release period, defined as the period from start of release (plus the travel time for the tracer gas to reach measuring point) until shut off of tracer gas. We excluded incomplete plume traverses, which could occur if there were no drivable roads to complete a full plume traverse. Plumes were also excluded where the measuring vehicle was stationary for any period of time, for example due to traffic queues or traffic lights. Typically, plume traverses clearly affected by other sources of methane emissions would be excluded. In this study, two additional methane emission sources (two old landfills directly south of the study site) were identified during the initial screening (section 3.1). The methane plumes from these sources were clearly defined, and did not interfere with the plume from the study site. In very few of the plume transects (two out of the nine plume transect measured during TDM3 road $1 \mathrm{~W} / 1 \mathrm{~N})$, an additional small methane source close to the measurement road resulted in a narrow, sharp additional spike in the methane concentration. The methane peak had been previously identified in background screening as a discrete methane source from a pile of manure that was clearly visible $\sim 50 \mathrm{~m}$ from the measuring road. This was removed in postprocessing. In total, about $81 \%$ of plume traverses passed the visual inspection.

Each plume transect passing visual screening was integrated individually to calculate the methane/tracer gas ratio. For each individual plume transect, the background concentration was subtracted. Background concentrations across the transect was established by drawing a straight line between the concentration in the air before entering and after leaving each plume i.e. the subtracted background concentration for each point in the transect could vary. The average methane emission rate for each TDM was calculated by taking the average of all the emission rates calculated from each transect that passed screening. Fig. 5a and $b$, show a typical plume traverse and the corresponding emission calculation.

The uncertainty of the averaged emission rate was calculated as a $95 \%$ confidence interval. This uncertainty includes all non-systematic uncertainties, including data handling (background subtraction and integration) and actual emission variation during the 
measurements. The sum of possible systematic uncertainties, such as uncertainty in the tracer release (bottle placement, number of bottles and accuracy of the release rate) and concentration measurements have been estimated to be less than $15 \%$ when measurements are carried out under optimal conditions. Other sources of measurement error that relate to incomplete mixing of the tracer gas with the emitting methane (e.g. improper emission simulation in both the horizontal and vertical plane) are anticipated to reduce with increased measuring distance from the site. Mønster et al. (2014) showed that misplacing the tracer gas 50 meters upwind of the source can give an overestimation of $36 \%$ when measurements were made close by ( $370 \mathrm{~m}$ from the controlled methane release), while the error decreased to $20 \%$ at $1200 \mathrm{~m}$. Misplacing the tracer gas $20 \mathrm{~m}$ perpendicular to the wind direction resulted in a much smaller quantification error between $-12 \%$ at $370 \mathrm{~m}$ and $+12 \%$ at $1200 \mathrm{~m}$. Taylor et al. (2016) assessed, through modelling, the error of emission quantification of a source (from a hotspot area covering about $17 \%$ of the landfill and emitting $80 \%$ of the total emission) where the tracer gas release was placed at the upwind edge, the downwind edge, $85 \mathrm{~m}$ upwind from the edge and at the centre of the hotspot area. The calculated error ranged from $42 \%$ for the extreme misplacement (at 750 meters measurement distance) to between 8 and $14 \%$ for misplacements at the edges (at 2000 meters measurement distance). Emission modelling of the same landfill investigated in this study using the Gaussian dispersion model AERMOD, showed that generally less than $10 \%$ error could be expected for measuring distances over $\sim 2 \mathrm{~km}$ (when assuming a homogenous area emission and modelling the real topography of the landfill - Matacchiera et al., 2018). In general, better mixing of the gasses results in a less biased emission result. The plumes of methane and tracer gas are spread vertically in the atmosphere and are mixed by atmospheric turbulence. However, the best mixing conditions are near the surface, where ground-induced turbulence mixes the gasses, possibly making surface measurements the most suitable place to perform plume traverses for the tracer dispersion method.

a)

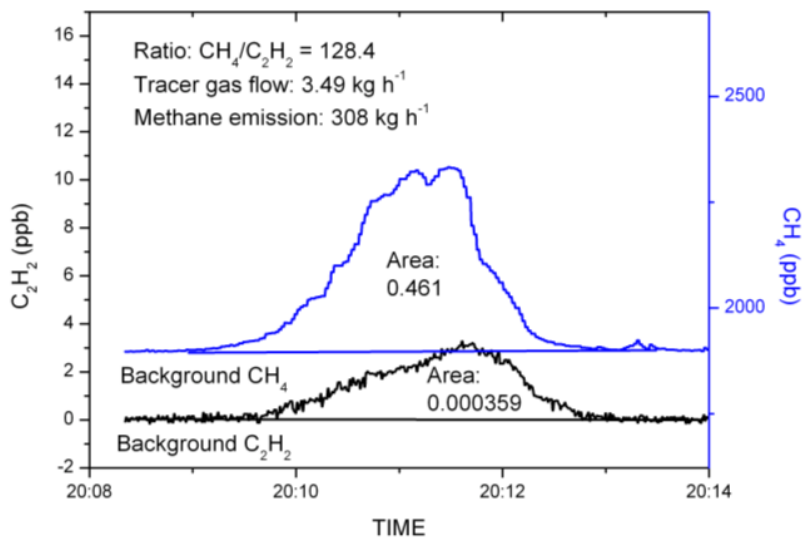

b)

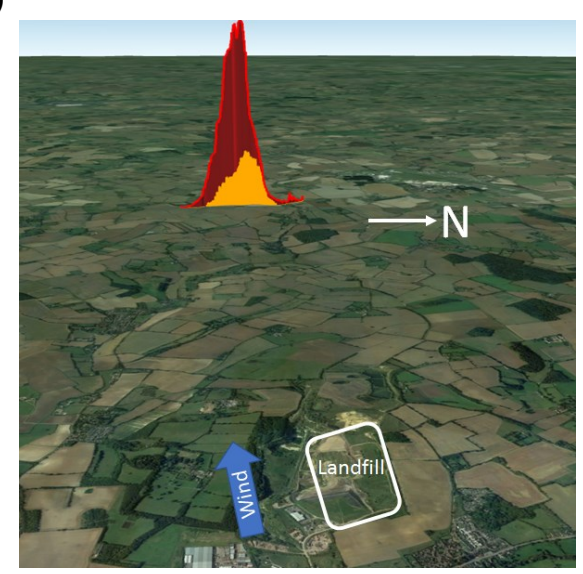

Fig. 5. a) Example of integrated methane and tracer gas plumes and the corresponding emission calculation. Data from August $7^{\text {th }}$, measured on road $3 \mathrm{~W}, 6700 \mathrm{~m}$ from the landfill, b) Geographical location of the plume in relation to the landfill. Relative methane (red) and acetylene (yellow) concentrations above background. Maximum methane concentrations above background were $436 \mathrm{ppb}$ and maximum acetylene concentrations above background were $3.3 \mathrm{ppb}$ (Google, 2017). 


\section{Results}

\subsection{Background screening around the landfill}

Initial screenings for methane and acetylene in the area around the landfill were carried out in the afternoon on August $5^{\text {th }}, 2014$. Background concentrations were determined from measurements along different roads in all directions around the landfill and taking the average of the measurements where no nearby interference sources were present. The average background concentration was $1.882 \mathrm{ppm}$ methane $( \pm 0.001)$ and $0.1 \mathrm{ppb}$ acetylene $( \pm 0.1)$.

Two other significant methane sources were identified; a closed and restored landfill approximately $1700 \mathrm{~m}$ to the south and an operational landfill approximately $2800 \mathrm{~m}$ to the southeast. Furthermore, a series of sharp methane concentration peaks were observed along a monitoring route $\sim 600 \mathrm{~m}$ east-southeast of the landfill. These peaks were likely due to methane (natural gas) leaks from pipelines along the road, and in some cases signs with warnings about possible explosive atmosphere were observed. An additional peak was identified as a pile of manure. All the interfering methane sources were considered to be far enough from the landfill and have relatively small concentrations measured immediately downwind. Measurements upwind of the interference source were conducted close to the landfill and no elevated methane concentrations were observed. No interference sources were, therefore, considered to contribute to the measured emission from the landfill.

\subsection{Whole landfill methane emission}

Fig. 6a to $6 \mathrm{f}$ show the methane emissions measured during each transect for each TDM. The data is summarised in Table 2.

No significant temporal emission variation within each TDM was seen (Fig. 6). In general, the $95 \%$ confidence interval of the average methane emission rate measured within one release campaign was less than $\pm 11 \%$ (based on data in Table 2). For methane emission rates averaged from each monitoring route for a given TDM, the confidence interval was less than $\pm 9 \%$ with exceptions of TDM2 ( $1 \mathrm{~W}$ and $2 \mathrm{~W}$ ) and TDM5 (1E) where it varied between \pm 17 to $\pm 20 \%$ (based on data in Table 2). During measurement periods with constant landfill emissions, the confidence interval is expected to decrease with increasing number of transects (Mønster et al., 2014).

The methane emission rates were higher on the first three days $(333 \pm 27,371 \pm 42$ and $\left.410 \pm 18 \mathrm{~kg} \mathrm{~h}^{-1}\right)$ compared to the last three days $\left(217 \pm 14,249 \pm 20\right.$ and $\left.263 \pm 22 \mathrm{~kg} \mathrm{~h}^{-1}\right)$. The influence of factors that might affect emission rates is examined and discussed in section 4.1. The methane emissions from the landfill, during the scoping campaign on the afternoon on June $11^{\text {th }}$ and morning June $12^{\text {th }}$ were $286 \pm 14$ and $323 \pm 24 \mathrm{~kg} \mathrm{~h}^{-1}$, respectively, which are within the emission range measured in the August campaign (TDM J1 and J2 in Table 2).

\subsection{Estimation of non-combusted methane from on-site gas engines}

The gas engines sited in the GUP may emit non-combusted methane, either from leakages or from inefficient combustion. The location of the GUP, close to the landfill and close to the site boundary (see Fig. 1) made it difficult to differentiate between any potential emissions from the GUP and emissions from the rest of the landfill. However on August $11^{\text {th }}$ (TDM4), the wind was from the west and was stable enough to see the individual plumes from the GUP and the remaining landfill downwind on road 1E. By integrating the plumes on an individual basis, the methane emission from the gas engine area was estimated to be between 14 and $22 \mathrm{~kg} \mathrm{~h}^{-1}$. Besides the uncertainty in the plume splitting, two other factors 


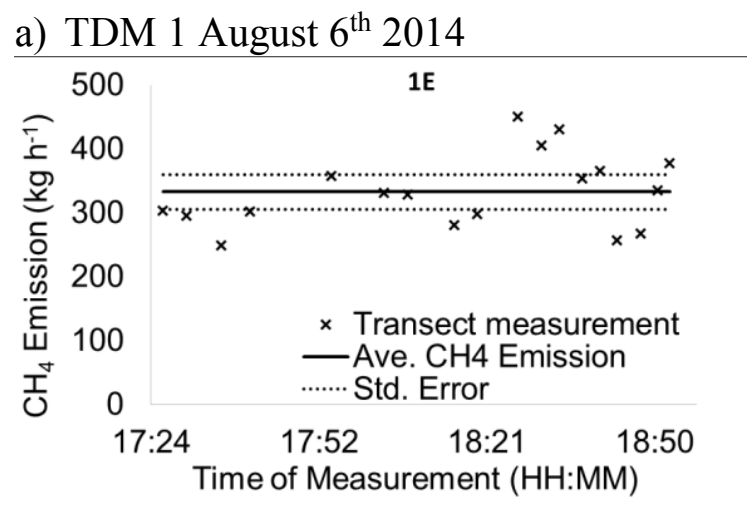

b) TDM 2 August $7^{\text {th }} 2014$

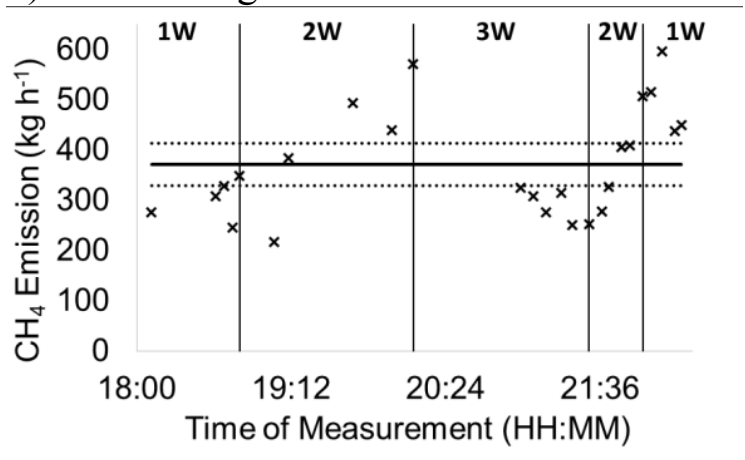

c) TDM 3 August $8^{\text {th }} 2014$

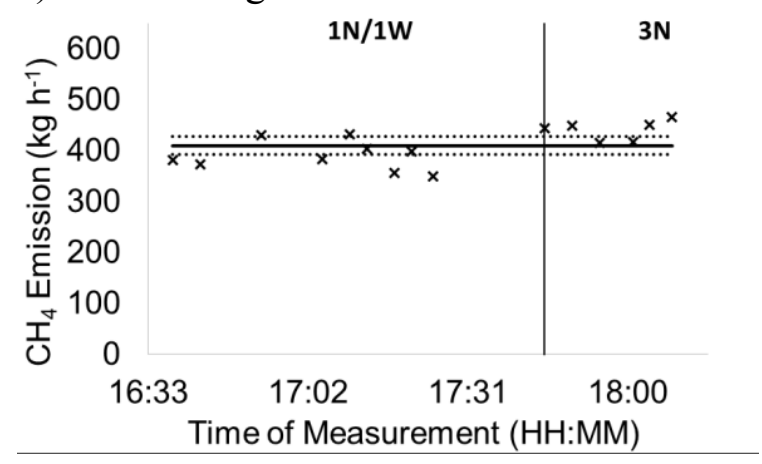

d) TDM 4 August $11^{\text {th }} 2014$

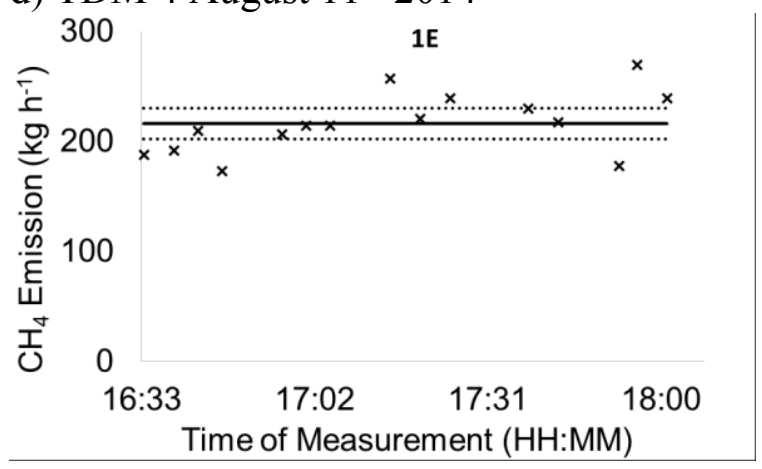

e) TDM 5 August $12^{\text {th }} 2014$
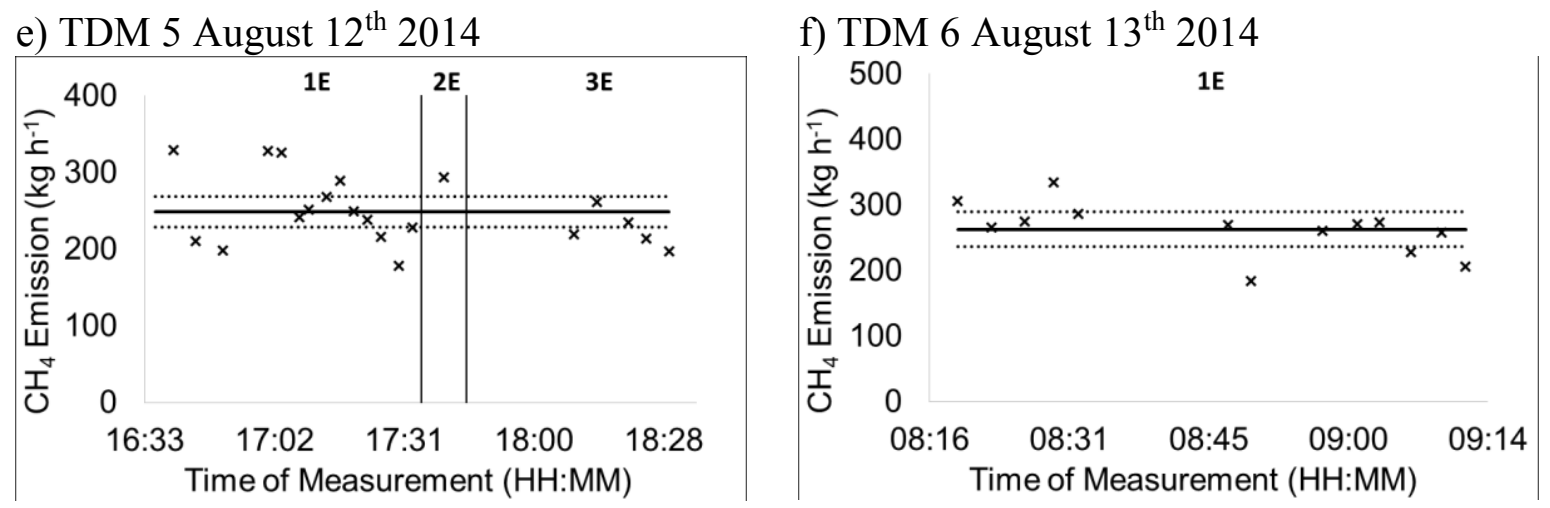

Fig. 6 (a to f). Methane emission data for each transect in a TDM with average overall emission and the $95 \%$ confidence interval. The name of the monitoring route used for a given transect is also shown. 
Table 2. The calculated methane emission rates $\left(\mathrm{kg} \mathrm{h}^{-1}\right)$ on the six measurement days in August 2014 and two previous measurement days in June 2014.

\begin{tabular}{|c|c|c|c|}
\hline $\begin{array}{l}\text { Test no. / } \\
\text { Date }\end{array}$ & $\begin{array}{c}\text { (Road) \& measuring distance to the } \\
\text { landfill (m) and total number of } \\
\text { plume transects used for } \\
\text { quantification }(n)\end{array}$ & $\begin{array}{l}\text { Methane emission rate } \\
\left(\mathrm{kg} \mathrm{h}^{-1}\right) \pm \text { confidence }^{\mathrm{a}} \\
\text { interval }\end{array}$ & $\begin{array}{l}\text { Overall average methane } \\
\text { emission rate } \\
\left(\mathrm{kg} \mathrm{h}^{-1}\right) \pm \text { confidence }^{\mathrm{b}} \\
\text { interval }^{\mathrm{c}}\end{array}$ \\
\hline TDM 1 & (1E) $1700-2000(18)$ & $333 \pm 27$ & $333 \pm 27$ \\
\hline TDM 2 & $\begin{array}{c}(1 \mathrm{~W}) 2000(9) \\
(2 \mathrm{~W}) 3500-4000(11) \\
(3 \mathrm{~W}) 6700(5)\end{array}$ & $\begin{array}{l}389 \pm 77 \\
357 \pm 69 \\
295 \pm 27\end{array}$ & $371 \pm 42$ \\
\hline TDM 3 & $\begin{array}{c}(1 \mathrm{~W} / 1 \mathrm{~N}) 1600-2000(9) \\
(3 \mathrm{~N}) 4500-5000(6)\end{array}$ & $\begin{array}{l}390 \pm 19 \\
441 \pm 16\end{array}$ & $410 \pm 18$ \\
\hline TDM 4 & (1E) $1700-2000(15)$ & $217 \pm 14$ & $217 \pm 14$ \\
\hline TDM 5 & $\begin{array}{l}(1 \mathrm{E}) 1700-3000(14) \\
(2 \mathrm{E}) 2500-4200(1) \\
(3 \mathrm{E}) 4800-6000(5) \\
\end{array}$ & $\begin{array}{c}254 \pm 26 \\
293 \\
225 \pm 21 \\
\end{array}$ & $249 \pm 20$ \\
\hline TDM 6 & (1E) 1700-2000 (13) & $263 \pm 22$ & $263 \pm 22$ \\
\hline TDM J1 & (1S) $1400-1700(5)$ & $286 \pm 14$ & $286 \pm 14$ \\
\hline TDM J2 & $(1 \mathrm{~S}) 1400-1700(11)$ & $323 \pm 24$ & $323 \pm 24$ \\
\hline
\end{tabular}

a The average methane emission rate based on the measurements performed at each measuring distance.

${ }^{b}$ The overall average methane emission rate based on all the measurements performed at each measuring time interval.

${ }^{\mathrm{c}}$ The uncertainty is given as a $95 \%$ confidence interval.

contribute to uncertainty: First, the methane emitting from the gas engine exhaust occurs from an elevated height and in the form of a warm gas, which may initially rise faster than the tracer gas release. The methane may, therefore, get more dispersed than the tracer gas resulting in an underestimation of the quantification. Second, the site's leachate treatment facility is close to the GUP. Screenings showed some elevated methane concentrations downwind from the treatment plant, which may also contribute to the downwind plume from the GUP, resulting in an overestimation of the emission from the gas engines themselves.

However, the estimated methane emission rate from the gas engines of between 14 and $22 \mathrm{~kg} \mathrm{~h}^{-1}$ represents a slippage rate (un-combusted methane) of between 2.1 and $3.3 \%$ based on a methane gas engine flow rate of $663 \mathrm{~kg} \mathrm{~h}^{-1}$ (Table 3). Considering the uncertainly of the estimate, this compares reasonably well to an average national UK value of $1.5 \%$ reported in a review of landfill methane emissions modelling (Defra, 2014).

\subsection{Gas recovery efficiency}

Table 3 shows LFG utilisation data for each of the measuring days. The average daily LFG recovery flow varied between 1780 and $1948 \mathrm{~m}^{3} \mathrm{~h}^{-1}$, with a methane content of between $48.9 \%$ and 50.8\%. The methane utilization rate varied between 633 and $679 \mathrm{~kg} \mathrm{~h}^{-1}$ at STP (1 atm, $0^{\circ} \mathrm{C}$ ). Data from the June campaign is given for comparison.

With a methane recovery of between 633 and $679 \mathrm{~kg} \mathrm{~h}^{-1}$, the gas collection efficiency was approximately $69 \%$, assuming that the methane generated is the sum of the methane recovered and the methane emitted to the atmosphere, thus not including any potential methane oxidation in areas having a soil cover.

On June $11^{\text {th }}$ and $12^{\text {th }}$, the methane recovery was between 700 and $754 \mathrm{~kg} \mathrm{~h}^{-1}$, respectively and the average gas collection efficiency was $70 \%$, which is similar to the average efficiency measured in August. 
Table 3. LFG utilisation data and calculated efficiency of recovery (June data given for comparison).

\begin{tabular}{|c|c|c|c|c|c|c|c|c|c|}
\hline \multirow{2}{*}{$\begin{array}{l}\text { Test no. / } \\
\text { Date }\end{array}$} & \multicolumn{3}{|c|}{$\begin{array}{l}\text { LFG composition } \\
\text { (\% vol.) }\end{array}$} & \multirow{2}{*}{$\begin{array}{l}\text { Sucti } \\
\text { on } \\
(\mathrm{mb})\end{array}$} & \multirow{2}{*}{$\begin{array}{c}\text { Flare } \\
\text { flow } \\
\left(\mathrm{m}^{3} \mathrm{~h}^{-1}\right)\end{array}$} & \multirow{2}{*}{$\begin{array}{l}\text { Total } \\
\text { site } \\
\text { flow } \\
\left(\mathrm{m}^{3} \mathrm{~h}^{-1}\right)\end{array}$} & \multirow{2}{*}{$\begin{array}{c}\text { Total } \\
\text { methane } \\
\text { collected } \\
\left(\mathrm{kg} \mathrm{h}^{-1}\right)\end{array}$} & \multirow{2}{*}{$\begin{array}{l}\text { Average } \\
\text { methane } \\
\text { emission } \\
\text { rate } \\
\left(\mathrm{kg} \mathrm{h}^{-1}\right) \\
\end{array}$} & \multirow{2}{*}{$\begin{array}{c}\text { Methane } \\
\text { recovery } \\
\text { efficiency } \\
(\%)\end{array}$} \\
\hline & $\mathrm{CH}_{4}$ & $\mathrm{CO}_{2}$ & $\mathrm{O}_{2}$ & & & & & & \\
\hline TDM 1 & 50.1 & 35.7 & 1.1 & -73.2 & 910 & 1890 & 670 & 333 & 67 \\
\hline TDM 2 & 48.9 & 34.3 & 1.5 & -78.5 & 887 & 1948 & 679 & 371 & 65 \\
\hline TDM 3 & 50.8 & 35.2 & 1.1 & -68.4 & 0.00 & 1830 & 663 & 410 & 62 \\
\hline TDM 4 & 50.1 & 34.3 & 1.3 & -68.7 & 0.00 & 1856 & 663 & 217 & 75 \\
\hline TDM 5 & 50.0 & 35.4 & 1.2 & -84.6 & 0.00 & 1830 & 652 & 249 & 72 \\
\hline TDM 6 & 49.9 & 36.2 & 1.1 & -69.3 & 0.00 & 1780 & 633 & 282 & 71 \\
\hline TDM J1 & 50.5 & 37.0 & 0.7 & -78.0 & 155 & 2094 & 754 & 286 & 73 \\
\hline TDM J2 & 50.1 & 36.6 & 0.7 & -78.0 & 159 & 2098 & 750 & 323 & 70 \\
\hline
\end{tabular}

a The gas collection efficiency is calculated as the collected methane divided by the sum of the collected methane and the emitted methane, neglecting methane oxidation.

Methane emission measurements using the tracer gas dispersion method conducted at the five Danish landfill sites employing active gas collection showed that the gas collection systems collected between 41 and $81 \%$ of the methane generated (Mønster et al., 2015). A similar large variation in recovery efficiency was also seen by Börjesson et al. (2009), who observed a recovery efficiency of $14-78 \%$ at seven Swedish landfills. Börjesson et al. (2009) also quantified methane oxidation between 6 and $43 \%$ using stable carbon isotopic fractionation, which was included in the efficiency calculation. In a recent study, the gas recovery efficiency was found to be between $59-76 \%$ at a large Danish landfill, while the methane oxidation efficiency was between 6-37\% (based on stable carbon isotopic analysis Aghdam et al., 2017). In a British study, where methane emissions were measured at nine landfills, gas collection efficiencies varied between 26 and $74 \%$ at operational landfills and between 23 and $85 \%$ at closed landfills (Bourn and Browell, 2013). These collection efficiencies included methane surface oxidation between 5 and $24 \%$, measured by stable carbon isotopes (Bourn and Browell, 2013). The gas collection efficiency depends on many factors including the design and management of the gas collection system, the presence and type of top cover, etc. The average gas collection efficiency of about $69 \%$ at the landfill is in the upper range of the gas collection efficiencies reported in the literature. Including methane oxidation in the current study would, however, reduce the gas collection efficiency. An oxidation efficiency of $10 \%$ or $20 \%$ in the landfill top cover would result in a gas collection efficiency of $66 \%$ and $64 \%$, respectively.

\section{Discussion}

\subsection{Correlation of methane emission rates with environmental (climatic) factors}

Over the six days of monitoring, the measured methane emission rate varied by over $100 \%$ from $\sim 217$ to $441 \mathrm{~kg} \mathrm{~h}^{-1}$ (Table 2). A number of mechanisms may affect methane emission rates from landfill, both environmental (e.g. barometric pressure) and operational (e.g. operation of LFG collection systems). In addition, there may be some experimental bias in the tracer dispersion technique that might influence the results obtained, for example whether full mixing of the tracer gas and methane has occurred at the measurement location. Separating any experimental bias from actual variations in emissions is however challenging. 
As shown in Fig. 3 and 4, meteorological conditions were variable during each campaign. As the resolution of the meteorological data was in 30 min intervals, meteorological values could not be attributed to individual transects. It was also, therefore, not possible to correct for the gas travel time for an individual transect, because unless the wind was constant, the travel time from leaving the emission source to the monitoring location would also be changeable.

The June data set was not included in the following discussion on potential factors influencing emissions, as environmental and operational conditions may have been different prior to and during the campaign (different landfill operation conditions, weather trends, etc.). The June data set was also limited to only two TDMs and far few traverses.

Barometric pressure. Gas transport mechanisms of advection and diffusion through the top cover of landfills will be influenced by the physical properties of the soil, such as air permeability, porosity and water content. The presence of preferential flow paths (i.e. fractures in the cover) promotes advective transport and may lead to localised point sources often referred to as "hot spots". Advection is also strongly influenced by barometric pressure changes associated with the passage of weather fronts and to a lesser extent by "wind pumping" mechanisms controlled by turbulent velocity fluctuations occurring at the landfillatmosphere interface (e.g. Czepiel et al., 2003). Rainfall, often associated with pressure fronts, can reduce advective flow by increasing the water content of top covers resulting in a reduction in air permeability.

Table 4 shows atmospheric data alongside the calculated emission rates - a more detailed version of this table with transects grouped according to distance is included as Table S1 in Supplementary Information (SI). No clear overall correlation was found between emission rate and the absolute pressure. However, the higher emissions measured during the first three days (Aug. $6^{\text {th }}$ to $8^{\text {th }}$ ) of the campaign $\left(333 \pm 27,371 \pm 42\right.$ and $410 \pm 18 \mathrm{~kg} \mathrm{~h}^{-1}$ ) were in general measured during a period of an overall pressure decrease (1014 to 987 mbar) starting August $5^{\text {th }}$ and lasting to August $10^{\text {th }}$. The highest methane emission $\left(410 \pm 18 \mathrm{~kg} \mathrm{~h}^{-1}\right)$ was measured during a period of 24 hours where the atmospheric pressure fell from about 1010 to 995 mbar. From August $10^{\text {th }}$ to $11^{\text {th }}$ the atmospheric pressure increased again (from 987 to 1003 mbar), and then fell slightly over the following days (August $11^{\text {th }}$ to $13^{\text {th }}$ ). The pressure increase and the following relatively stable pressure period may explain the lower methane emissions $\left(217 \pm 14,249 \pm 20\right.$ and $\left.263 \pm 22 \mathrm{~kg} \mathrm{~h}^{-1}\right)$ measured during the last three days of the campaign (August $11^{\text {th }}$ to $13^{\text {th }}$ ). However, plots of methane emission rates versus changes in atmospheric pressures indicate a fairly weak correlation $\left(\mathrm{R}^{2}=-0.20,-0.31\right.$ and -0.27$)$ between emission rate and changes in atmospheric pressure over a 6,12 and 24 hour period prior to the TDM test (Table S2 in SI).

Relatively few studies have looked at the influence of barometric pressure on landfill emissions and most did not measure whole site emissions variations in response to barometric pressure changes but rather looked at changes in surface fluxes, LFG flows or LFG compositions. The majority of the studies (Xu et al., 2014; Fredenslund et al., 2010; Gebert and Groengroeft, 2006; Poulsen et al., 2003; Nastev et al., 2001; Young, 1992 \& 1990) observed that it is the change in barometric pressure, rather than its absolute value, that affects the emission from a landfill. However, Czepiel et al. (2003) found that measured methane emissions at Nashua municipal landfill, USA, were inversely correlated with the absolute value of barometric pressure. The highest methane emission of $1590 \mathrm{~m}^{3} \mathrm{CH}_{4} \mathrm{~h}^{-1}$ was measured at a pressure of 1007 mbar, while the lowest methane emission of $438 \mathrm{~m}^{3} \mathrm{CH}_{4} \mathrm{~h}^{-1}$ was measured at a pressure of 1023 mbar (Czepiel et al., 2003). Christophersen et al. (2001) found that LFG emissions measured by flux chambers at a Danish landfill were 
Table 4. Calculated methane emission rates with climatic data and GUP data (June data given for comparison).

\begin{tabular}{|c|c|c|c|c|c|c|c|c|c|c|}
\hline $\begin{array}{c}\text { Test no. / } \\
\text { Date }\end{array}$ & $\begin{array}{l}\text { Overall avg. } \\
\text { methane } \\
\text { emission rate } \\
\left(\mathrm{kg} \mathrm{h}^{-1}\right) \pm \\
\text { confidence } \\
\text { interval }\end{array}$ & $\begin{array}{l}\text { Wind } \\
\text { speed } \\
(\mathrm{SD}) \\
\left(\mathrm{m} \mathrm{s}^{-1}\right)\end{array}$ & $\begin{array}{c}\text { Wind } \\
\text { directio } \\
n \\
(\mathrm{SD}) \\
\text { (Degree } \\
\mathrm{s})\end{array}$ & Sector & $\begin{array}{l}\text { Avg. } \\
\text { temp. } \\
\text { (SD) } \\
\left({ }^{\circ} \mathrm{C}\right)\end{array}$ & $\begin{array}{c}\text { Solar } \\
\text { radiatio } \\
\mathrm{n} \\
(\mathrm{SD}) \\
\left(\mathrm{W} \mathrm{m}^{-2}\right)\end{array}$ & $\begin{array}{c}\text { Avg. } \\
\text { atmos. } \\
\text { pressure } \\
\text { (SD) } \\
\text { (mbar) }\end{array}$ & $\begin{array}{c}\text { Overall } \\
\text { pressure } \\
\text { trend }\end{array}$ & $\begin{array}{c}12 \text { hour } \\
\text { pressure } \\
\text { trend }^{\mathrm{a}}\end{array}$ & $\begin{array}{c}\text { GUP } \\
\text { flow } \\
\text { rate } \\
\left(\mathrm{m}^{3} \mathrm{~h}^{-1}\right)\end{array}$ \\
\hline TDM 1 & $333 \pm 27$ & $\begin{array}{c}7.5 \\
(1.4) \\
\end{array}$ & $\begin{array}{c}266 \\
(29.5) \\
\end{array}$ & W & $\begin{array}{l}24.8 \\
(0.6) \\
\end{array}$ & $\begin{array}{l}129.0 \\
(85.0) \\
\end{array}$ & $\begin{array}{c}1005.0 \\
(0.4)\end{array}$ & Rising & Falling & 1890 \\
\hline TDM 2 & $371 \pm 42$ & $\begin{array}{c}3.4 \\
(2.3)\end{array}$ & $\begin{array}{c}93 \\
(8.1)\end{array}$ & $\mathrm{E}$ & $\begin{array}{l}18.4 \\
(1.1)\end{array}$ & $\begin{array}{c}45.9 \\
(66.4)\end{array}$ & $\begin{array}{c}1010.7 \\
(0.4)\end{array}$ & Rising & Rising & 1948 \\
\hline TDM 3 & $410 \pm 18$ & $\begin{array}{c}4.3 \\
(2.2) \\
\end{array}$ & $\begin{array}{c}124 \\
(12.0) \\
\end{array}$ & SE & $\begin{array}{l}20.1 \\
(0.3) \\
\end{array}$ & $\begin{array}{c}52.3 \\
(43.1) \\
\end{array}$ & $\begin{array}{c}999.2 \\
(0.8) \\
\end{array}$ & Falling & Falling & 1830 \\
\hline TDM 4 & $217 \pm 14$ & $\begin{array}{l}9.3 \\
1.3) \\
\end{array}$ & $\begin{array}{c}225 \\
(0.0) \\
\end{array}$ & SW & $\begin{array}{l}17.6 \\
(0.4)\end{array}$ & $\begin{array}{l}192.2 \\
(91.7)\end{array}$ & $\begin{array}{c}1001.8 \\
(0.1)\end{array}$ & Stable & Rising & 1856 \\
\hline TDM 5 & $249 \pm 20$ & $\begin{array}{c}9.7 \\
(0.9)\end{array}$ & $\begin{array}{c}239 \\
(12.6)\end{array}$ & WSW & $\begin{array}{l}18.5 \\
(0.6)\end{array}$ & $\begin{array}{c}314.2 \\
(197.1)\end{array}$ & $\begin{array}{c}1000.0 \\
(0.1)\end{array}$ & Stable & Falling & 1830 \\
\hline TDM 6 & $263 \pm 22$ & $\begin{array}{c}7.8 \\
(0.7)\end{array}$ & $\begin{array}{c}270 \\
(0.0)\end{array}$ & W & $\begin{array}{l}16.9 \\
(1.1)\end{array}$ & $\begin{array}{l}491.3 \\
(38.0)\end{array}$ & $\begin{array}{c}998.7 \\
(0.2)\end{array}$ & Stable & Falling & 1780 \\
\hline TDM J1 & $286 \pm 14$ & $\begin{array}{c}4.2 \\
(1.6) \\
\end{array}$ & $\begin{array}{c}315 \\
(0.0) \\
\end{array}$ & NW & $\begin{array}{l}20.3 \\
(0.2) \\
\end{array}$ & $\begin{array}{c}98.5 \\
(30.4) \\
\end{array}$ & $\begin{array}{c}1022.6 \\
(-)\end{array}$ & Rising & Rising & 2094 \\
\hline TDM J2 & $323 \pm 24$ & $\begin{array}{c}3.4 \\
(1.7)\end{array}$ & $\begin{array}{c}315 \\
(0.0)\end{array}$ & NW & $\begin{array}{l}20.9 \\
(0.8)\end{array}$ & $\begin{array}{c}654.0 \\
(130.8)\end{array}$ & $\begin{array}{c}1023.9 \\
(0.1)\end{array}$ & Rising & Rising & 2098 \\
\hline
\end{tabular}

a The 12 hour trend is the change in atmospheric pressure leading up to the start of each campaign.

inversely correlated with both barometric pressure and changes in barometric pressure, but a better correlation was observed with changes in barometric pressure. Similar conclusions were drawn by Aghdam et al. (2018) who found that recovered LFG flow, its methane content, and the recovered methane flow were highly correlated with both the absolute value of barometric pressure and changes in barometric pressure. However, a higher correlation was observed when studying the changes in barometric pressure in comparison to the absolute value of barometric pressure (Aghdam et al., 2018).

It is possible that the emission response to barometric pressure changes is not only a result of the short-term pressure change prior to or during a measuring event, but is also linked to more long-term pressure development prior to measuring such as the longevity of the pressure change, the number of pressure changes following each other, etc. As an example, the impact on methane emissions from a long term pressure decrease or of several small pressure decreases following each other would be highest in the beginning and decrease with time as the LFG in the waste volume is depleted. Also the LFG generation rate and the design of the landfill are expected to influence the correlation between emission and barometric pressure changes.

Wind speed. The variable most strongly correlated with emission rates was wind speed $\left(\mathrm{R}^{2}=-0.82\right.$, Fig. 7 ), with lower emissions measured at higher wind speeds. Studies have suggested wind induced advective gas transport to be a potential methane emission mechanism (resulting in pressure pumping) caused by development of pressure fields on the landfill surface during windy conditions (Poulsen, 2005; McBain et al., 2005; Massman et al., 1997). A modelling study (Poulsen, 2005) has shown that wind turbulence can impact gas emissions from landfills, especially in winter when the moisture content of the cover soil is higher and winds are stronger. Aghdam et al. (2018) found LFG recovery data were highly correlated with wind speed during winter, but not during summer, where the average wind speed was about half of the average wind speed during winter. The correlation seen during winter periods was positive with LFG methane concentration and negative with LFG flow, 
meaning that higher wind speeds resulted in higher LFG methane concentrations and lower LFG flows (Aghdam et al., 2018). McBain et al. (2005) found a positive correlation $\left(\mathrm{R}^{2}=\right.$ $0,477, n=138$ ) between wind speed and landfill methane fluxes measured using a micrometeorological mass balance method.

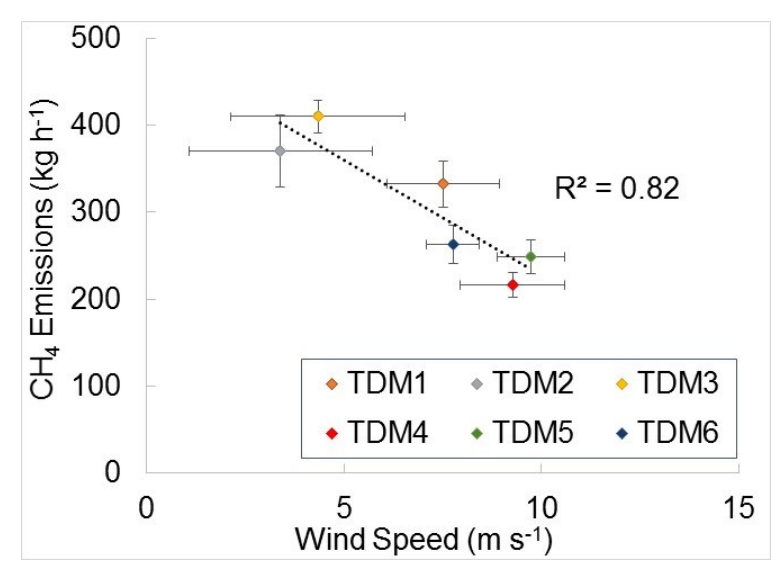

Fig. 7. Measured methane emissions vs. average wind speed for the six TDM trials. Linear regression is given $\left(\mathrm{R}^{2}=-0.82\right)$.

In general increased wind speed - when strong enough - would be expected to result in increased surface emissions due to a decrease in the local pressure of the impacted area. However, when wind is blowing across a landfill with irregular topography (such as at the landfill studied) some surface areas or slopes of the landfill will experience an increase in local pressure whereas other will experience a decrease. Due to the irregular topography of the landfill, changes in local pressure will be impacted by the wind direction and the topography at the specific part of the landfill. Furthermore, any effect of wind speed and wind direction on surface emissions will depend on the landfill cover conditions (soil type, thickness, moisture content, etc.), landfill operation and the emission pathways at the landfill area receiving the wind induced effect.

It may not be the wind speed itself that is driving the change in emissions, rather the mechanism or combination of mechanisms that are driving the changes in wind speed, for example changing atmospheric pressure. At present it is not possible to confirm that this relationship is a direct effect of wind speed on the actual emission or and indirect effect from other factors.

One alternative potential factor could be an introduction of experimental bias in the tracer gas dispersion technique, which causes over estimations of measured emissions when measurements are performed under low wind speeds. As Fig. 3 demonstrates, during TDM2, wind speed dropped over the course of the monitoring, with wind speeds reducing from $6.7 \mathrm{~m}$ $\mathrm{s}^{-1}$ at the start to almost zero. There is a wind speed threshold below which the TDM technique may not work (e.g. at zero wind speed there will be no dispersion of the plume downwind), so it is to be anticipated that there will be some relationship between wind speed and confidence interval, especially at low wind speeds. However, the relationship is potentially complicated as other meteorological factors are likely to have an influence, including the location of the atmospheric boundary layer, solar radiation and vertical temperature gradients and the degree of turbulent mixing.

Incomplete vertical mixing of the source and tracer gases at the measurement location may also have an influence. Matacchiera et al. (2018) demonstrated with the Gaussian dispersion model AERMOD, that unless full vertical mixing had been achieved, TDMs could 
result in overestimates (by over $25 \%$ ) of actual emissions in the case of an idealised homogenous emission source with trace gas release in the centre of the source. They further demonstrate, that reducing wind speeds increases the distance at which full vertical mixing conditions are established downwind of the source (Matacchiera et al., 2018). There is some limited support for this theory in Fig. 8a and 8b, which show individual transect data against the estimated wind speed, interpolated between wind measurements to correspond to the time of the peak concentration in each transect. Early on in the monitoring of TDM2 wind speeds were above $5 \mathrm{~m} \mathrm{~s}^{-1}$, and resulted in methane emission values of approximately $300 \mathrm{~kg} \mathrm{~h}^{-1}$ at a distance of $\sim 2000 \mathrm{~m}$ (route $1 \mathrm{~W}$ ) (Fig. 8a). These emission values correspond to those obtained at a distance of $\sim 6700 \mathrm{~m}$ (route $3 \mathrm{~W}$ ) measured when the wind speed was about $2 \mathrm{~m}$ $\mathrm{s}^{-1}$ (Fig. 8b). Late time monitoring of route $1 \mathrm{~W}$, when wind speeds had dropped to less than $0.5 \mathrm{~m} \mathrm{~s}^{-1}$, resulted in emission values of approximately $500 \mathrm{~kg} \mathrm{~h}^{-1}$ (Fig. 8b). These higher values fit with the theory that full mixing at these lower wind speeds may not have been achieved at a distance of $2000 \mathrm{~m}$, resulting in a possible overestimation of emission values due to experimental error. The same trend is, however, not seen in the data from monitoring route $2 \mathrm{~W}$ (3500 to $4000 \mathrm{~m}$ ). Higher methane emission rates were measured in the early data $\left(\sim 420 \mathrm{~kg} \mathrm{~h}^{-1}\right.$ at a wind speed of $\left.\sim 4 \mathrm{~m} \mathrm{~s}^{-1}\right)$ (Fig. 8a), than in the late data $\left(\sim 335 \mathrm{~kg} \mathrm{~h}^{-1}\right)$, when the wind speed had dropped to between 1 and $2 \mathrm{~m} \mathrm{~s}^{-1}$ (Fig. 8b). No significant correlation between emissions and wind speed was noted during TDM1, 3, 4, 5 or 6 , most likely because there was little change in the wind speed (less than $0.2-1 \mathrm{~m} \mathrm{~s}^{-1}$ ) during these campaigns. 

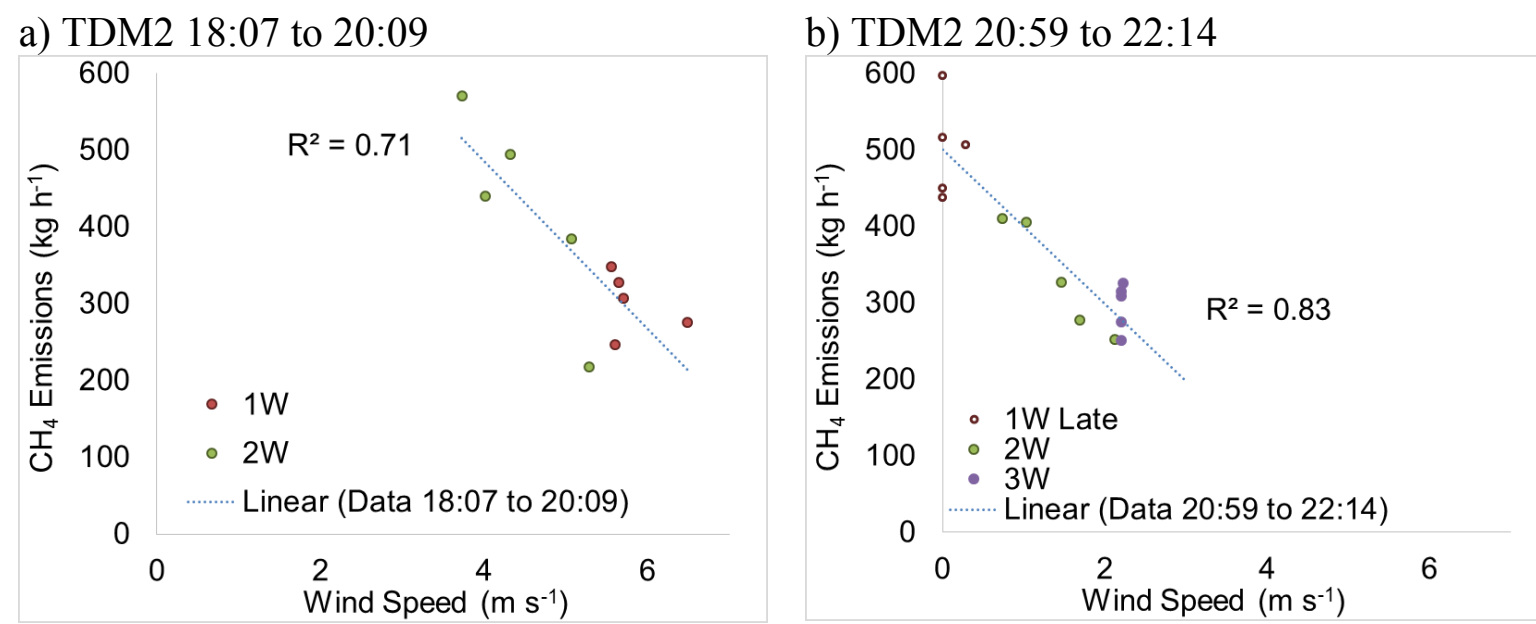

Fig. 8. Individual transect data from TDM2 shown against estimated wind speed, interpolated between measurement points. Data are colour coded to reflect the monitoring route used. a) shows data between 18:07 and 20:09, and b) 20:59 to 22:14.

Temperature and solar radiation. The majority of the TDM surveys were undertaken during unstable atmospheric conditions with positive heat fluxes. No overall correlation was found between whole site methane emissions and air temperature and solar radiation. (Table S2 in SI). Temperature and solar radiation primarily affect atmospheric stability conditions and the degree of mixing promoted by turbulence. Increased turbulence could reduce the thickness of the interfacial surface layer and reduce the resistance to molecular diffusion between the landfill cover and the atmosphere causing increased methane fluxes (McBain et al., 2005). Most of the measurement campaigns were carried out in the late afternoon or evening when solar radiation was decreasing, which might result in a reduction in emissions. However, as no correlation was seen between solar radiation and methane emissions, most likely diffusion was not the dominating process governing surface methane emissions.

\subsection{Correlation of methane emission rates with plant operational factors}

Operational factors are considered to relate to the operation of the landfill site, and in particular to the performance of the GUP. In theory, LFG pressure inside the landfill and the bulk permeability of the landfill cap or cover layers will also be important, but no information was collected on these aspects during the monitoring campaign.

The GUP operates either two or three engines at a time. When two engines are running, the excess gas is diverted through a flare, such that the average hourly flow through the plant remains fairly constant. Two engines and the flare were running on August $7^{\text {th }}$ and $8^{\text {th }}$, and three on all other measurement dates, including during the June experiments. There was no significant correlation between the GUP flow and the methane emission rates (Table S2 in SI), although the range in measured flow in the GUP was fairly small, between 1780$2098 \mathrm{~m}^{3} \mathrm{~h}^{-1}$ (Table 4). Also there was no correlation between measured emission rate and the LFG methane content, the suction pressure, the collected methane rate, or the gas collection efficiency (Table S2 in SI). A final observation from the correlation matrix (Table S2 in SI) is that there was a strong correlation $\left(\mathrm{R}^{2}=0.98\right)$ between the performance of the GUP (in terms of rate of gas removed) and absolute atmospheric pressure. 


\subsection{Correlation of methane emission rates and measurement distance}

Fig. 9a shows average methane emission data for each monitoring route for each TDM test against the average measurement distance from the landfill. No relationship is apparent. However, as shown in Fig. 9b, for TDM2, 3 and 5, where different monitoring routes were used to measure the plumes (Fig. 2), the average data from each distance may show evidence of possible experimental bias. For TDM2 and 5, lower emissions were measured at increasing distance from the landfill. It is possible, that at closer distances, full mixing of the two gas plumes had not have been achieved, which has resulted in an over estimation of the methane emission. However, as discussed, it is difficult to separate the influence of distance on measured emissions from other potential factors such as changes in the meteorological conditions during the course of the experiment. The same trend was not seen in TDM3, which may be due to the topography of the landfill itself. In TDM3, the wind was from the south, and may have been affected by the ridge between the operational area and the fully restored area. This may have created turbulence resulting in better mixing between the methane and the acetylene compared to wind coming from east or west (TDM 2 and 5).

a)

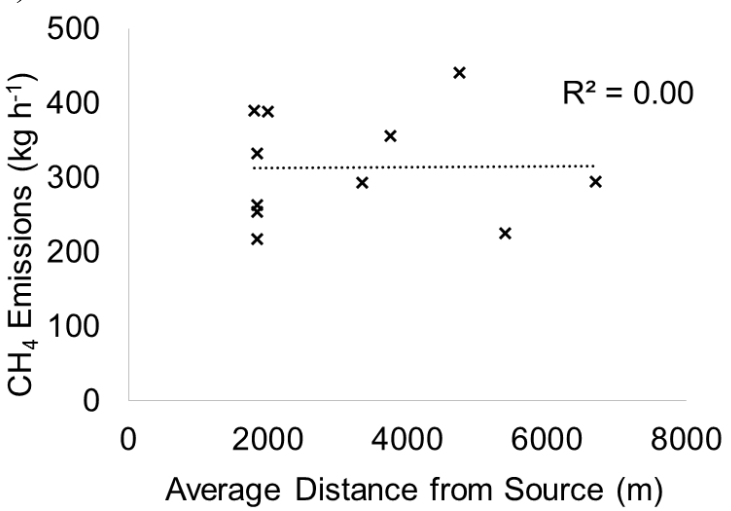

b)

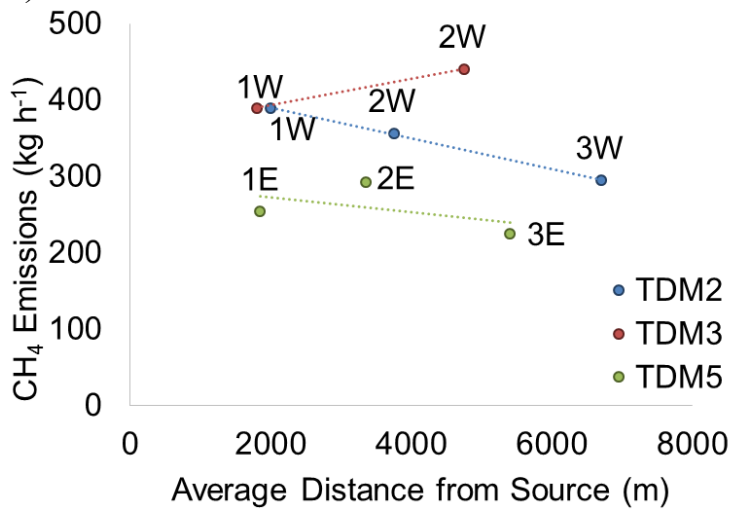

Fig. 9. a) Average methane emission data from each monitoring route shown against measuring distance, $b$ ) Average methane emission rate from each monitoring route for a given TDM measured at different monitoring distances.

\section{Conclusion}

The methane emissions from the landfill during the six days of the measurement campaign were successfully quantified using the tracer dispersion method. The fair weather conditions made it necessary to perform measurements in the late afternoon and in the evening when the lower solar flux resulted in a more stable troposphere with a lower inversion layer. This caused a slower mixing of the gasses, but allowed plume measurements up to $6700 \mathrm{~m}$ downwind from the landfill.

The average methane emission varied between $217 \pm 14$ and $410 \pm 18 \mathrm{~kg} \mathrm{~h}^{-1}$ within the individual measurement days, but the measured emission rates were higher on the first three days $\left(333 \pm 27,371 \pm 42\right.$ and $\left.410 \pm 18 \mathrm{~kg} \mathrm{~h}^{-1}\right)$ compared to the last three days $(217 \pm 14,249 \pm 20$ and $\left.263 \pm 22 \mathrm{~kg} \mathrm{~h}^{-1}\right)$. The higher emissions measured during the first three days of the campaign were measured during a period with an overall decrease in atmospheric pressure (from approximately 1014 mbar August $5^{\text {th }}$ to 987 mbar August $10^{\text {th }}$ ). The lower emissions measured during the last three days of the campaign were carried out during a period with an initial pressure increase followed by a period of stable pressure.

For short (2-3 hours) duration tests, the $95 \%$ confidence interval was calculated as $\pm 7.4 \%$. This may increase as the test duration increases, owing to actual changes in emission 
rates driven by climatic or operational controls, which would become more significant with time.

Previous research has demonstrated that emissions from a landfill will be influenced by meteorological events such as changing atmospheric pressure, although the mechanism is not yet fully understood. A weak negative correlation between pressure changes (as opposed to absolute pressure) was observed over the measurement period. A stronger correlation was observed between wind speed and emissions, with higher wind speeds resulting in lower emission measurements. It has not been possible to fully identify whether these variations are a reflection of real changes in emission rates or are caused by potential experimental error.

There is still a lack of knowledge about the dynamics in landfill emissions magnitude and frequency of emission response due to pressure changes (as an example). It is advised that future studies focus on evaluation the temporal emission variation from whole site as well as from different landfills sections, as these may vary significantly depending on weather conditions such as precipitation, atmospheric pressure, wind and temperature.

The average daily methane recovery varied between 633 and $679 \mathrm{~kg} \mathrm{~h}^{-1}$ at STP (1 atm, $0^{\circ} \mathrm{C}$ ). The methane emitted to the atmosphere accounted for approximately $31 \%$ of the total methane generated, assuming that the methane generated is the sum of the methane recovered and the methane emitted to the atmosphere. This does not, therefore, include potential methane oxidation in the landfill cover soil.

In general, the methane emissions as well as the recovery efficiency measured in the August campaign compared very well with the emissions and recovery efficiencies measured in June. The methane emissions from the landfill, during the afternoon on June $11^{\text {th }}$ and morning June $12^{\text {th }}$ were $286 \pm 14$ and $323 \pm 24 \mathrm{~kg} \mathrm{~h}^{-1}$, respectively. During these two days the methane recovery was between 700 and $754 \mathrm{~kg} \mathrm{~h}^{-1}$, and the methane emitted to the atmosphere accounted for approximately $30 \%$ of the total methane generated.

\section{Acknowledgement}

This project was part funded by Department for Environment Food \& Rural Affairs (Defra), UK. The project was carried out as part of a larger methane quantification and method comparison study, co-ordinated by the Natural Environment Research Council (NERC), UK funded GAUGE consortia. This work was supported by EPSRC platform grant: 'Processes, mechanics \& management of residual wastes' (EPSRC GR/T25194/01). This study included data produced by the Technical University of Denmark. Summary data supporting this paper are openly available from the University of Southampton, UK repository at http://doi.org/10.5258/SOTON/D0391.

\section{References}

Abichou, T., Clark, J, Chanton, J., 2011. Reporting central tendencies of chamber measured surface emission and oxidation. Waste Manag. 31, 1002-1008.

Aghdam, E.F., Fredenslund, A.M., Chanton, J., Kjeldsen. P., Scheutz, C., 2017.

Determination of gas recovery efficiency at two Danish landfills by performing downwind plume methane measurements and stable carbon isotope isotopic analysis. Submitted to Waste Manag. In press. https://doi.org/10.1016/j.wasman.2017.11.049

Aghdam, E.F., Scheutz, C., Kjeldsen. P., 2018. Impact of meteorological parameters on extracted landfill gas composition and flow. Submitted to Waste Manag. in July 2017. Revised version submitted in December 2017.

Bogner, J.E., Spokas, K.A., Chanton, J.P., 2011. Seasonal greenhouse gas emissions from engineered landfills. Journal of Environmental Quality. 40, 1010-1020.

Bogner, J., Pipatti, R., Hashimoto, S., Diaz, C., Mareckova, K., Diaz, L., Kjeldsen, P., Monni, S., Faaij, A., Sutamihardja, R. T. M., et al., 2008. Mitigation of global greenhouse gas 
emissions from waste: conclusions and strategies from the Intergovernmental Panel on Climate Change (IPCC) Fourth Assessment Report. Working Group III (Mitigation). Waste Manag. Res. 26, 11-32.

Bourn, M. \& Browell, D. 2013. Methane capture rates at UK landfills. Proceedings at Fourteenth International Waste Management and Landfill Symposium, Sardinia, Italy.

Börjesson, G., Samuelsson, J., Chanton, J., Adolfsson, R., Galle, B., Svensson, B.H. Tellus B., 2009. A national landfill methane budget for Sweden based on field measurements, and an evaluation of IPCC models, Tellus B, 61, 424-435.

Börjesson, G., Samuelsson, J., Chanton, J., 2007. Methane oxidation in Swedish landfills quantified with the stable carbon isotope technique in combination with an optical method for emitted methane. Environmental Science \& Technology, 41, 6684-6690.

Christophersen M., Kjeldsen, P., 2001. Lateral gas transport in soil adjacent to an old landfill: factors governing gas migration. Waste Manag. Res. 19 (2), 579-594.

Christophersen, M., Holst, H., Chanton, J., Kjeldsen, P., 2001. Lateral gas transport in soil adjacent to an old landfill: factors governing emissions and methane oxidation. Waste Manag. Res. 19 (2), 595-612.

Czepiel, P. M., Shorter, J. H., Mosher, B., Allwine, E., McManus, J. B., Harriss, R. C., Kolb, C. E.,Lamb, B. K., 2003. The influence of atmospheric pressure on landfill methane emissions. Waste Manag. 23, 593-598.

Dalkesh, M., Zhou, B., Han, B., Chow, F., Rella, C. W. and Imhoff, P. T. 2016. Short-term landfill methane emissions dependency on wind, Waste Manag. 55, 288-298.

Defra, 2014. Review of landfill methane emissions modelling. Draft report prepared by Golder Associates ref. 13514290381.503/B.0.

Fredenslund, A. M., Scheutz, C. Kjeldsen, P., 2010. Tracer method to measure landfill gas emissions from leachate collection systems. Waste Manag. 30, 2146-2152.

Galle, B., Samuelsson J., Svensson B.H., Börjesson G., 2001. Measurements of methane emissions from landfills using a time correlation tracer method based on FTIR absorption spectroscopy. Environmental Science \& Technology, 35, 21-25.

Gebert, J., Groengroeft, A., 2006. Passive landfill gas emission - influence of atmospheric pressure and implications for the operation of methane-oxidising biofilters. Waste Manag. 26 (3), 245-251.

Google Earth v7.1.8.3036., 2017. Infoterra Ltd. \& Bluesky 2017. Viewed July 2017 $<$ https://www.google.com/earth/index.html $>$.

Environment Agency, 2004. Guidance on the management of landfill gas LFTGN 03.

Environment Agency, 2010. Guidance on monitoring landfill gas surface emissions LFTGN07 2nd ed.

IPCC, 2007: Climate Change 2007: The Physical Science Basis. Contribution of Working Group I to the Fourth Assessment Report of the Intergovernmental Panel on Climate Change. [Solomon, S., Qin, D., Manning, M., Chen, Z., Marquis, M., Averyt, K.B., Tignor, M. \& Miller, H.L. (eds.)]. Cambridge University Press, Cambridge, UK and New York, NY, USA.

Massman, W.J., Sommerfeld, R.A., Mosier, A.R., Zeller, K.F., Hehn, T.J., Rochelle, S.G., 1997. A model investigation of turbulence-driven pressure-pumping effects on the rate of diffusion of CO2, N2O, and CH4 through layered snowpacks. J. Geophys. Res. 102, 18851-18863.

Matacchiera, F., Manes, C., Rees-White, T., Beaven, R., F Boano, F., Mønster, J., and Scheutz, C., 2018. The use of Gaussian dispersion modelling as a planning tool for tracer gas dispersion tests for measurement of landfill methane emissions. Submitted to Waste Manag. August 2017. 
McBain, M.C., Warland, J.S., McBride, R.A., Wagner-Riddle, C., 2005.

Micrometeorological measurements of $\mathrm{N} 2 \mathrm{O}$ and $\mathrm{CH} 4$ emissions from a municipal solid waste landfill. Waste Manag. Res. 23, 409-419. doi:10.1177/0734242X05057253

Molins, S., Mayer, K.U., Scheutz, C., Kjeldsen, P., 2008. Transport and reaction processes affecting the attenuation of landfill gas in cover soils. Journal of Environmental Quality, 37 (2), 459-468.

Mønster, J. G., Samuelsson, J., Kjeldsen, P., Rella, C. W., Scheutz, C., 2014. Quantifying methane emission from fugitive sources by combining tracer release and downwind measurements - A sensitivity analysis based on multiple field surveys. Waste Manag. 34, $1416-1428$.

Mønster, J., Samuelsson, J., Kjeldsen, P., Scheutz, C., 2015. Quantification of methane emissions from 15 Danish landfills using the mobile tracer dispersion method. Waste Manag. 35, 177-186.

Nastev, M., Therrien, R., Lefebvre, R., Gélinas, P., 2001. Gas production and migration in landfills and geological materials. J. Contam. Hydrol. 52, 187-211.

Park J.W., Shin, H. C., 2001. Surface emission of landfill gas from solid waste landfill. Atmospheric Environment, 35, 3445-3451.

Poulsen, T.G., Christophersen, M., Moldrup, P., Kjeldsen, P., 2003. Relating landfill gas emissions to atmospheric pressure using numerical modelling and state-space analysis. Waste Manag. Res. 21, 356-366.

Poulsen, T.G., 2005. Impact of wind turbulence on landfill gas emissions. Proc. Sardinia 2005, Tenth Int. Waste Manag. Landfill Symp. S. Margherita di Pula, Cagliari, Italy; 3 - 7 Oct. 2005.

Poulsen, T.G., Møldrup, P., 2006. Evaluating effects of wind-induced pressure fluctuations on soil-atmosphere gas exchange at a landfill using stochastic modelling. Waste Manag. Res. 24, 473-481.

Rachor, I.M., Gebert, J., Gröngröft, A., Pfeiffer, E.-M., 2013. Variability of methane emissions from an old landfill over different time-scales. European Journal of Soil Science, 64(1), 1626.

Robinson, R., Gardiner, T., Innocenti, F., Woods, P., Coleman, M., 2011. Infrared differential absorption Lidar (DIAL) measurements of hydrocarbon emissions. Journal of Environmental Monitoring, 13 (8), 2213-20. http://doi.org/10.1039/c0em00312c

Scheutz, C., Pedersen R. B., Petersen, P. H., Jørgensen J. H. B., Ucendo, I. M. B., Mønster, J. G., Samuelsson, J. Kjeldsen, P., 2014. Mitigation of methane emission from an old unlined landfill in Klintholm, Denmark using a passive biocover system. Waste Manag. 34, 11791190.

Scheutz, C., Fredenslund, A. M., Chanton, J., Pedersen, G.B., Kjeldsen, P., 2011a. Mitigation of methane emission from Fakse landfill using a biowindow system. Waste Manag. 31, 1018-1028.

Scheutz, C., Samuelsson, J., Fredenslund, A. M., Kjeldsen, P., 2011b. Quantification of multiple methane emission sources at landfills using a double tracer technique. Waste Manag. 31, 1009-1017.

Scheutz, C., Kjeldsen, P., Bogner, J. E., De Visscher, A., Gebert, J., Hilger, H. A., HuberHumer, M., Spokas, K., 2009. Microbial $\mathrm{CH}_{4}$ oxidation technologies for mitigation of LFG emissions. Waste Manag. Res. 27, 409-455.

Scheutz, C., Bogner, J., Chanton, J.P., Blake, D., Morcet, M., Aran, C., Kjeldsen, P., 2008. Atmospheric emissions and attenuation of non-methane organic compounds in cover soils at a French landfill. Waste Manag. 28, 1892-1908.

Scheutz, C., Kjeldsen, P., 2004. Environmental factors influencing methane oxidation and cooxidation of HCFCs in landfill cover soils. Journal of Environmental Quality, 33, 61-71. 
Scheutz, C., Bogner, J., Chanton, J., Blake, D., Kjeldsen, P., 2003. Comparative oxidation and net emissions of $\mathrm{CH}_{4}$ and selected non-methane organic compounds in landfill cover soils. Environmental Science \& Technology, 37 (22), 5150-5158.

Uyanik, I., Ozkaya, B., Demir, S., Cakmakci, M., 2012. Meteorological parameters as an important factor on the energy recovery of landfill gas in landfills. J. Renew. Sustain. Energy 4, 1-9.

Xu, L., Lin, X., Amen, J., Welding, K., McDermitt, D., 2014. Impact of changes in barometric pressure on landfill methane emission. Global Biogeochem. Cycles, 28, 679695.

Young, A., 1992. The effects of fluctuations in atmospheric pressure on landfill gas migration and composition. Water, Air, Soil Pollut. 64, 601-616.

Young, A., 1990. Volumetric changes in landfill gas flux in response to variations in atmospheric pressure. Waste Manag. Res. 8, 379-385. 